\title{
NÄYTTÖTUTKINNOT ETSIVÄT PAIKKAANSA
}

\author{
Kyösti Kontio
}

Vaikka näyttötutkintouudistuksesta on syytä iloita, on tutkinnossa vielä kosolti petraamisen varaa. Tutkinnon läpäisyn helppoudessa tai vaativuudessa on horjuvaa käytäntöä, määrä tuntuu olevan laatua tärkeämpi ja järjestelmässä noudatetaan perinteistä ammatillisen koulutuksen mallia, missä kaikki osallistuvat samanlaiseen koulutukseen riippumatta erilaisista henkilökohtaisista taidoista.

\begin{abstract}
Wäyttötutkintojärjestelmän arviointitutkimukhin valmistavan koulutuksen, alkuarvioinnin, näyttöjen, näyttöjen arviointia ja koko järjestelmän toimivuutta. Aineisto kerättiin vuosilta 1997-98, ja mukana oli 21 oppilaitosta, 61 arvioijaa, 218 tutkinnon suorittajaa eli kokelasta sekä työnantajia 37. Tutkimuksessa oli mukana hierojan, laitoshuoltajan, koneistajan, rakennusmiehen ja yrittäjän ammattitutkinnon järjestäjät ja suorittajat. Tutkimuskohteet valittiin Tilastokeskuksen tiedostoja hyväksikäyttäen ottamalla harkinnanvaraisesti otos niistä oppilaitoksista, jotka järjestivät tutkintoja ja/tai valmistavaa koulutusta vuoden 1997 aikana. Aineiston keruumenetelminä olivat postikysely ja haastattelu.
\end{abstract}

Näyttötutkintojärjestelmän keskeinen lähtökohta on laki ammatillisesta aikuiskoulutuksesta (631/1998), jonka mukaan näyttöihin osallistumiselle ei tule asettaa ennakkoehtoja, toisin sanoen osallistujalta ei edellytetä esimerkiksi tiettyä koulutusta tai työkokemusta. Kuitenkin tutkintoon hakeutujalle tulee tehdä alkuarviointi hänen senhetkisestä osaamisestaan ja verrata sitä tavoitteena olevaan ammattitaitoon tai osaamiseen. Arvioitavia asioita ovat myös työkokemus ja opinnot, harrastuneisuus ja motivaatio, itseohjautuvuus ja valmiudet monimuoto-opiskeluun sekä opiskelijan oma arvio lähtötasostaan. (Kinnala 1996.)

ikaisemman opitun hyväksiluku on tuotta-
nut oppilaitoksille melkoisesti vaikeuksia. Miten otetaan huomioon aikaisemmat koulutukset ja työkokemukset? Vastaavuuden arviointi on teettänyt opettajille paljon työtä, ja siitä huolimatta aikaisempaa oppimista ei ole voitu paljoakaan ottaa huomioon. Tässä tutkimuksessa alkuarviointi oli tehty alle kolmannekselle kokelaista. Niilläkin, joille oli tehty jonkinlainen haastattelu ja/tai kirjallinen arviointi, se oli jätetty hyödyntämättä HOPS:n laadinnassa. Koulutukseen osallistuneista noin puolelle oli laadittu henkilökohtainen opetussuunnitelma, mutta sitäkin oli hyödynnetty hyvin vähän koulutuksessa. (Kontio 1999.) Myös Haltian ja Lemiläisen (1997) tutkimuksen mukaan henkilökohtaisten opetussuunnitelmien laatiminen oli ollut hyvin vähäistä. 


\section{UU T T A KO ULU T US T U T K I M U K S E S T A}

$\mathrm{N}^{3}$ äyttötutkintojärjestelmä ei muuttanut paljoakaan opetussuunnitelmia ja -menetelmiä, vaan oppilaitokset toimivat totutun käytännön mukaan. Tutkinnon suorittajat arvostelivatkin koulutusta liiallisesta teoreettisuudesta ja koulumaisesta opetuksesta. Toivottiin enemmän opiskelun siirtämistä todelliseen työelämään, ja tällaisten jaksojen tulisi olla teoriajaksoja pitemmät. Opetussuunnitelmissa tulisi näkyä enemmän työelämän edustajien kädenjälki. Useissa kommenteissa tuli esille, että opetussuunnitelmaa ei oltu esitelty koulutuksen aikana tai mikäli suunnitelma oli, sitä ei noudatettu. Kommenteissa kehotettiin valvomaan "keskuksia", että ne todella opettaisivat juuri niitä osa-alueita, joita lupaavat. "Ammattikurssikeskukset vain rahastavat", oli erään kokelaan arvio. "Emme saaneet luvattua koulutusta." Opetussuunnitelma - jos sellainen oli ollut - oli hyvin staattinen, eikä sitä voinut muokata joustavasti opiskelijan tarpeiden mukaan. (Kontio 1999.)

Sen sijaan oppilaitosten edustajien mukaan opetussuunnitelmat ovat joustavia, ja HOPS:t ovat opiskelijoiden aktiivisessa käytössä. Niitä voidaan muuttaa koulutuksen aikana, ja opiskelijan sosiaaliset opiskelumahdollisuudet voidaan ottaa täten huomioon. Tässä on jälleen havaittavissa piilo-opetussuunnitelman (se, miten käytännössä toimitaan) ja virallisen opetussuunnitelman (kirjallinen opetussuunnitelma) välinen ero. Joustava opetussuunnitelma voi tietenkin pitää paikkansa joillakin opiskelijoilla, mutta koko opiskelijajoukossa se ei näytä vielä toimivan. Näyttötutkintojärjestelmässäkin noudatetaan perinteistä ammatillisen koulutuksen mallia, jossa kaikki osallistuvat samanlaiseen koulutukseen riippumatta erilaisista henkilökohtaisista taidoista. Tutkinnon suorittajista 90 prosenttia osallistuikin valmistavaan koulutukseen, joka oli eniten auttanut näyttökokeiden läpäisyssä. Myös työkokemuksesta oli apua etenkin vanhemmilla tutkinnon suorittajilla. Aikaisemmasta muusta ammatillisesta koulutuksesta ei ollut merkittävää apua näytöissä. Tämä on hyvinkin huomioon otettava seikka, sillä hyväksiluvussa voidaan ottaa huomioon aikaisempi koulutus, joka ei välttämättä olekaan riittävä eli ajan tasalla tutkinnon suorittamishetkellä.
Tärjestelmän lähtökohtana on, että myös näytöt tulee suorittaa koulutusjakson kuluessa, eikä koulutuksen päätteeksi. Näyttökokeisiin osallistuneista 60 prosentille oli tehty "päättökokeita" koulutuksen lopussa. Tällainen päättötutkintoajattelu on vastoin näyttötutkintojärjestelmän joustavuuden periaatetta (Lähdesmäki 1996). Kaksi kolmasosalle kokelaista näytöt olivat työtehtäviä ja simulaatio- ja teoriatehtäviä. Tehtävistä yli puolet oli opettajien tekemiä, ja perinteisestihän opettajat tekevät teoriakokeita. Jotta näytöt tulisivat lähemmäksi työelämää, tulisi työelämän edustajien osallistumista lisätä näyttöjen laadinnassa. Näytöt suoritetaan suuressa määrin oppilaitoksissa. Mm. Mansfield (1989) toteaa, että pätevyyden osoittamisen ja arvioinnin tulee tapahtua todellisessa työympäristössä kaikkine siihen liittyvine paineineen, joita ei ehkä oppilaitoksissa suoritetuissa näytöissä esiinny.

Esimerkiksi rakennusalan ammattitutkintoa suorittanut kokelas kirjoitti, että Berliinissä ei ollut oikein aikaa näyttökokeille, eivätkä näytöt vastanneet siellä tehtyjä töitä. Kirjallisia tehtäviä oli rakennettu Suomessa eikä niitä voinut siellä toteuttaa. Yhden mielestä "näyttökoe ei ole hyvä, se on koetilanne, joka ei ole todellinen, kun tietää että toinen katsoo, mitä teet ja teetkö oikein." Yksi kokelas huomautti, että "lyhyen kurssin suorittaneet saavat ammattitutkinnon liian helposti." Joillekin oli pidetty näyttökokeet kahden viikon päästä koulutuksesta omalla ajalla. Muutamat kokelaat mainitsivat suorittaneensa näytöt kahden vuoden kuluttua koulutuksen jälkeen. Jotkut eivät olleet suorittaneet näyttöjä lainkaan. Esimerkiksi "vanha näyttö" riitti tutkinnon saamiseksi. Yksi kokelas kirjoitti: ”Oli 
viiden tunnin koulutus ja sen jälkeen ilmoitettiin, että olen saanut tutkinnon suoritettua." Hänen mielestään tutkinnon arvostus meni sen tien. Useat kokivat, että näytöt olivat yleisesti ottaen liian helppo läpäistä, joten huonollakin ammattitaidolla sai tutkinnon. Se vaikuttaa kokelaiden mielestä tutkintojen laatuun ja luotettavuuteen. Tässä tutkimuksessa 93 prosenttia kokelaista läpäisi näytöt ensimmäisellä yrittämällä (Kontio 1999).

$\mathrm{S}$ en sijaan Haltia ja Lemiläinen (1997, 65, 90) livat todenneet tutkimuksessaan päinvastaisen ilmiön, eli että joissakin ammateissa näyttökokeet olivat olleet liian vaativia. Esimerkiksi sähköyliasentajan erikoisammattitutkinnon läpäisi yksi noin kolmestakymmenestä osanottajasta. Muun muassa sähköasennusalan näyttökokeiden vaatimukset ovat olleet siinä määrin korkeat, että tutkinnon läpäisseiden osuudet ovat jääneet pieniksi. Tämäkin osoittaa sen, että eri ammateissa tutkintovaatimukset vaihtelevat käytännössä suuresti.

Tutkintotoimikunnan, joka vastaa mm. tutkintojen järjestämisestä, valvonnasta, järjestämissopimuksista, todistuksista ym., käyttämä ulkojäsenen kommentoi näytön arviointitilanteesta seuraavaa: "Minun piti arvioida papereiden perusteella, näkemättä työn tekijää ja työn laatua, yli 20 -vuoden takaista uima-altaan laatoitusta ja hyväksyä hänelle muurarin ammattitutkinto. Esitin työn tarkistamista ja lisäperusteluja siitä, oliko työ tehty asiallisesti ja 'tämän päivän' vaatimusten mukaisesti. Minulle sanottiin, että kokelas-työntekijä on ammattimies, joten hänen tulee saada tutkinto... En moiti tutkintotoimikuntaa, mutta onko joku toimitsija parempi arvioimaan työn laatua kuin sitä työkseen tekevä ammattilainen? En hyväksynyt työtä, mutta toisten jäsenten toimesta työ hyväksyttiin. Minut "vapautettiin' myöhemmin asiantuntijan tehtävistä.” (Kontio 1999.)

Tämä kommentti antaa kuvan järjestelmän alkuvaiheessa suoritettujen tutkintojen hyväksymisen vaikeudesta. Oppilaitokset toimivat hyvinkin eri tavoin valmistavassa koulutuksessa ja näyttöjen toteuttamisessa. Eräänä syynä voidaan pi- tää kokemattomuutta eli tutkintojen suorittaminen tapahtuu eri tavalla, mihin opettajat ovat tottuneet. Toisaalta em. tapauksessa toteutettiin lain suomaa mahdollisuutta hankkia pätevyys aikaisemmilla työsuorituksilla. Toisaalta ulkojäsen halusi saada tutkinnon suorittajalta näytön nykyisestä ammattitaidosta, sillä ammattitaitokin tulee pitää ajan tasalla. Haltia ja Lemiläinen (1997, 78) ovat todenneet, että mitä laajempia tutkinnot ovat, sitä riittämättömämmäksi useimmissa tapauksissa osoittautuu pelkkä työkokemus. Onhan yleisesti keskusteltu siitä, että henkilön tulisi päivittää ammattitaitonsa noin 3-5-vuoden välein. Olettaisin, että ulkojäsenen kokemus ei ole ainutlaatuinen, jota osoittaa myös muutamien tutkinnon suorittajien kommentit tässäkin tutkimuksessa.

$A_{\text {silön pätevyys yhdellä tai useammalla taval- }}^{\text {rviointiprosessin tarkoituksena on mitata yk- }}$ la. Arvioinnin suorittavat tavallisesti työntekijöiden, työnantajien ja opettajien edustajat. Tähän liittyen on paljon keskusteltu siitä, miten arviointi tulisi toteuttaa. Arvioidaanko jokainen moduuli ja siihen sisältyvät eri tehtävät kerralla vai pitäisikö arviointia suorittaa pitkällä aikavälillä erilaisissa työtilanteissa eikä vain arvioida joitakin yksittäisiä toimintoja? Näytöissä oli arvioitu niin tehtäviä, moduuleja kuin koko tutkintoakin. Useissa tapauksissa oli käytetty jatkuvan arvioinnin periaatetta, jota on myös suositeltu Ison Britannian NVQ (National Vocational Qualilifications) -tutkinnoista saaduissa tutkimustuloksissa (Review 1996). Lähtökohtana tulisi arvioinnissa olla koko työprosessi eikä yksinomaan lopputulos, jota yleisesti käytetään koulutuksessa.

Myöskään arviointi ei ollut kaikkien mielestä oikeudenmukaista. Arvioijien ja kokelaiden väliset henkilökohtaiset suhteet eivät aina toimineet hyvin arviointitilanteissa, mikä osalla kokelaista vaikutti arviointiin. Kokelaiden mukaan arvioinneissa oli suuriakin eroja niin arvioijien kuin tutkintojenkin välillä. Erään kokelaan mukaan arvioijan tulisi antaa palaute asiallisin perustein, eikä arvioijan omien tunnepurkausten mukaan. Hänen esimerkkinsä oli: ”Jos arvioijalla on epäselvää, miksi näyttökokeen suorittajalla on 
paitapusero ja bermudat, voisi kysyä, miksi kyseinen työasu, eikä kysymättä antaa miinusta." Erään kokelaan vastauksessa luki, että "arvioijan tulee puhua arvioitavalle palautetta antaessa asiallisesti, eikä huutaa ja haukkua syyttä suotta, jos suoritus on kelvannut toiselle arvioijalle." Tämän tyyppiset esimerkit osoittavat, kuinka subjektiivista ja tunnepohjaistakin toisen ihmisen arviointi on.

\section{Arvioijien taustaa ja kokemuksia}

$\mathrm{K}^{2}$ aikki arvioijat kokivat vaikeimmaksi ja hanklasti arvioitaviksi sosiaaliset ja työssä oppimisen kehittymistaidot, varsinkin lyhyellä ajalla. Keskeisempänä haittana arvioijat pitivät arvioinnin järjestämistä työpaikalla oman työn ohella: oma työ jäi tekemättä, ja sijaisten saaminen arviointitilaisuuden ajaksi oli vaikeaa ja työnantajalle kallista. Ammattitutkintojen taitovaatimusten osia kuvattiin käyttämällä Olluksen ym. (1990) esittämää jaottelua, jonka perusteella tutkimusaineisto ryhmiteltiin harkinnanvaraisesti faktorianalyysin avulla viiteen taitovaatimuksen osioon. (1) ammatin osaaminen, (2) työkyky, (3) sosiaalisuus, (4) itsenäinen työtaito ja (5) työssä oppiminen (Kontio 1998, 1999).

Yli puolella arvioijista ei ollut minkäänlaista näyttökokeisiin valmistavaa arviointikoulutusta. Viidenneksellä oli päivän, parin perehdytyskoulutusta. Useat ilmoittivatkin erääksi puutteeksi vähäisen tietämyksen ja kokemuksen tällaisessa arvioinnissa.

Opetushallituksen toimesta järjestetään arvioijien näyttötutkintomestarikoulutusta lähinnä oppilaitosten opettajille. Tutkintoja järjestävät oppilaitokset taas huolehtivat työelämän arvioijien perehdyttämisestä, mikä jää usein hyvin vähäiseksi. Siksi olisi tärkeää saada myös työelämän edustajat opetusviranomaisten kustantaman arviointikoulutuksen piiriin.

$\mathrm{A}^{\mathrm{r}}$ rvioinnissa heijastuu perinteinen tapa arviida lopputulosta. Useiden tutkijoiden mukaan näyttöön perustuva arviointi antaa mahdollisuuden käyttää prosessiarviointia. Se antaa luotettavamman kuvan ammattitaidosta kuin pelkkä lopputuloksen arviointi, jossa näytön antajan ei tarvitse olla edes läsnä tulosta arvioitaessa. Tosin prosessiarviointikaan ei ole ratkaisu kaikkiin arvioinnin ongelmiin, huomauttaa Poikela (1998, 44). Vaikka näyttötutkintojärjestelmä antaa mahdollisuuden monipuolisiin ja joustaviin näyttö- ja arviointitapoihin, niin kuitenkin arvioijien keskuudessa korostettiin enemmän jatkuvan arvioinnin periaatetta, kuin lyhytkestoisia arviointeja.

\section{Pohdintaa}

Koska ammattitaidon voi hankkia monin eri tavoin, on myös ammatillisen koulutuksen muututtava. Se haastaa opetushenkilöstön kokeilemaan ja etsimään erilaisia opetus- ja oppimispedagogisia malleja, jotka auttavat eri tavoin tapahtuvaa yksilöllistä oppimista. Erilaiseen oppimiseen liittyy myös arviointimenetelmien muuttaminen, sillä uusien ja vanhojen opetus- ja arviointimenetelmien sekakäyttö aiheuttaa ongelmia niin oppijoille kuin opettajillekin. Poikelan (1998) mukaan ongelma liittyy nimenomaan arviointiin, sillä jos uusien oppimismenetelmien tuloksellisuutta mitataan vanhoilla arviointimenetelmillä, opiskelun vanhat mallit säilyvät. Tällöin oppimisen uudistaminen ei tuota toivottua tulosta eli oppijoiden ammattitaidon kohottamista ja työn laadun kehittämistä. On myös hyvin tärkeää seurata työelämän muuttumista, joka puolestaan aiheuttaa muutoksia työn suoriutumisvaatimuksissa.

Nykyään työelämä korostaa persoonallisuuteen liittyviä seikkoja, kuten vuorovaikutustaitoja, ryhmätyötaitoja, taitoa oppia uutta ja motivoituneisuutta. Tämänhetkisissä ammattitaitovaatimuksissa lähtökohtana ovat tuotannolliset eli työn osaamiseen liittyvät tiedot ja taidot, joten normatiivisten ja innovatiivisten taitojen alueet ovat jääneet vähemmälle huomiolle. Oma kysymyksensä on, kuinka paljon noihin taitoihin tai ominaisuuksiin voidaan vaikuttaa koulutuksen ja harjoittelun avulla ja määritelläänkö ne ammattitaitovaatimuksiksi?

Tutkimukseen osallistuneet eri toimijat kehit- 
täisivät myös näyttöjen arviointia. Heidän mukaansa arviointi tulisi saada luotettavammaksi ja oikeudenmukaisemmaksi oppilaitoksesta ja paikkakunnasta riippumatta. Myös näyttöjen hyväksymisessä tulisi pitää osaamisen laatua korkealla. Mikäli oppilaitos pyrkii kilpailemaan hyväksyttyjen tutkintojen määrällä eikä laadulla, se näkyy hyvin pian koko järjestelmässä eikä vain oppilaitoksen arvostuksessa. Työelämä reagoi nopeasti, mikäli tutkinnot eivät vastaa sen tarpeita.

$\mathrm{T}$ yöelämän ja koulutuksen lähentyminen on yksi tärkeimmistä tehtävistä näyttötutkintojen suorittamisessa ja kehittämisessä. Näyttää siltä, että kouluelämän rooli on merkittävä järjestelmän toteuttamisessa. Toisaalta kuitenkin koulumaisuus ja jäykkä opetussuunnitelmien noudattaminen saa kritiikkiä niin tutkinnon suorittajilta kuin työelämältäkin. Lisäksi työnantajien voimakkaampi mukaantulo antaisi vahvemman perustan tutkintojen suorittamiseen.

Yhteiskunnassamme on meneillään koulujärjestelmän laadunarviointibuumi. Eri oppilaitoksia ollaan laittamassa paremmuusjärjestykseen ja näin pyritään näyttämään koulutuksemme korkeatasoisuus. Tapa, jolla laatua arvioidaan, on muuttunutkin vain määräksi, joka antaa kriteerit koulujärjestelmän rahoituksen järjestämiseksi. Näyttötutkintojen laadun kehittämiseen ei ole käytännössä annettu resursseja. Kuitenkin juuri se on tässä vaiheessa tärkeimpiä rahoituksen kohteita, mikäli näyttötutkintojärjestelmä aiotaan kehittää toimivaksi ja käyttökelpoiseksi tavaksi aikuisille hankkia tutkinto näyttökokein.

Kuriositeettina nykyisestä käytännöstä voisi mainita esimerkin tutkinnon suorittaneelle annetuista tutkintotodistuksista. Tutkinnon suorittaja saa lain ja asetuksen (631/1998 ja 812/1998) sekä opetushallituksen ohjeen (kirjeet 2.9.1999) mukaan kolmesta viiteen eri todistusta. Mikäli henkilö suorittaa tutkinnon esimerkiksi lääninhallituksen rahoittamana koulutuksena, hän saa tutkintotoimikunnan antaman tutkintotodistuksen lisäksi oppilaitoksen todistuksen arvioineen tutkinnon osioiden suorittamisesta ja opintorekisteriotteen oppiaineista numerosuorituksineen. Mikäli hän suorittaa tutkinnon esimerkiksi op- pisopimuksella, hän saa näiden todistuksen lisäksi oppisopimustoimiston antamat kaksi todistusta. Tutkinnon suorittaneella opiskelijalla on siis yhteensä viisi todistusta. Nostaako todistusten määrä tutkinnon laatua vai järjestäjien arvostusta?

Kriittisyydestä huolimatta niin työnantajien kuin työntekijöidenkin edustajat pitävät näyttötutkintojärjestelmää kohtuullisen hyvänä mallina suorittaa ammatillisia tutkintoja. Tärkeimpiä kehittämisen alueita kaikkien tutkimuksessa mukana olevien ryhmien mielestä on saada kolmikantayhteistyö toimimaan paremmin, jotta tutkintoon liittyvät käytännön järjestelyt saataisiin toimimaan paremmin asetettujen tavoitteiden mukaisesti.

\section{Lähteet}

Ammatillinen aikuiskoulutuksen laki (630/1998). Helsinki: Valtioneuvosto.

Ammattitutkintoasetus (811/1998). Helsinki: Valtioneuvosto.

HALTIA, P. ja Lemiläinen, M. (1997). Ammattitutkintojen alkutaival. Tutkintorakenne ja kokemuksia ammattitutkintojen toteutuksesta. Turun yliopisto: Koulutussosiologian tutkimuskeskus. Moniste. Julkaisematon.

KINNALA, S. (1996). Henkilökohtaiset opiskeluohjelmat ammatillisessa aikuiskoulutuksessa. Helsinki: Opetushallitus.

KONTIO, K. (1999). Näytöillä ammattitutkinto. Työelämäntutkintojen näyttökokeiden ja niihin valmistavan koulutuksen arviointi. Moniste 21/1999. Helsinki: Opetushallitus.

KONTIO, K. (1998). Näytöillä ammattitutkintoon. Teoksessa P. Sallila ja T. Vaherva (toim.) Arkipäivän oppiminen. Helsinki: Aikuiskasvatuksen 39. vuosikirja, 200-218.

KONTIO, K. (1999). Näytöillä ammattitutkinto. Näyttötutkintojärjestelmän arviointia. Kasvatustieteiden tiedekunta. Lisensiaattitutkimus. Lapin yliopisto.

LÄHDESMÄKI, T. (1996). Koulutus- ja tutkintotoimikuntien puheenjohtajien tapaaminen 29.10. 1996, esitelmä. Helsinki.

MANSFIELD, B. (1989). Competence and standards. Teoksessa J. Burke (toim.) Competence based education and training. London: Falmer Press.

Opetushallituksen kirje 2.9.1999. Oppisopimuskoulutuksen järjestäjille DNO 38/011/99. Helsinki.

Opetushallituksen kirje 2.9.1999. Ammatillisen koulutuksen ja ammatillisen aikuiskoulutuksen järjestäjille DNO 37/011/99. Helsinki.

POIKELA, E. (1998). Oppiminen, arviointi ja osaaminen. Teoksessa A. Räisänen (toim.) Hallitaanko ammatti? Pätevyyden määrittelyä arvioinnin perustaksi. Helsinki: Opetushallitus. Arviointi 2/ 1998 